\title{
FRAMEWORK FOCAL CONTACTS IN EUROPEAN \\ PRIVATE INTERNATIONAL LAW AND EUROPEAN \\ UNION PRIVATE INTERNATIONAL LAW
}

Musić Nijaz ${ }^{1}$

Ministry of internal affairs, Bosnia-Podrinjski Canton
Review paper

UDC: $341.94(4)$

Received: 13.02 .2016

\begin{abstract}
The paper describes the role and representation of framework focus contacts in private international law, and their function in collision regulation on determining the binding law in private law with an element of foreignness. The introduction provides a brief overview on the division of focus contacts and their representation in collision regulations in the contemporary private international law. It also lays out various solutions for the application of collision regulations in national legislations in certain European countries, such as: Austria, Germany, Switzerland, Poland, Italy, Macedonia, Slovenia, as well as the solutions offered by the European Union regulations and international conventions.
\end{abstract}

Key words: (framework focus contacts, closest connection criterion, Regulation (EC) 864/2007, Regulation (EC) 593/2008, Rome Convention).

\section{TERM AND FUNCTION OF FOCAL CONTACTS}

Relations with international element, in theory of private international law appear under different names ("foreign element", "international character" etc.), which are nameing the same phenomenon, ie. the fact that in addition to elements that are related to State of Court there are appearing elements in factual framework related to another, foreign country.

Foreign element can be to generally accepted viewpoint occur in three basic forms, namely: in the subject (citizenship, residence, domicile, habitual residence, seat of the parties to the legal relationship), in the object (place of finding object) and in the rights and obligations (that the rights and obligations of that relationship are based outside the borders of the forum). Although rightly considered a foreign element to be "differentia specifica" of private international law, then the element that separates the private internation- al of substantive private law, it is necessary however to give an answer to the question, whether any foreign element is relevant? It should certainly be mentioned that the existence of any foreign element to some specific situation at any intensity, is a sufficient and necessary reason that in this particular case that on this speciffic case can be applyed provisions on handling cases with foreign element, that is,provisions of private international law. So collision norms are in most national legislations of imperative legal nature, which means that they impose an obligation on the authority to resolve the controversial private legal relationship with an international element to consult them and to act upon them. Of course there are exceptions so that some legislation, following a bypass way, do not allow collision norm to be applicated if one of the parties requested on time and in the prescribed form.

\footnotetext{
${ }^{1}$ Correspondence to:

Nijaz Musić, Ministry of internal affairs, Bosnia-Podrinjski Canton

Rada Jovanovića bb., Goražde

Phone: +38161388266

E-mail: nijaz975@hotmail.com
} 
In a number of countries (eg, France), this feature is given as an option (which means it is not an obligation) that the court can apply of collision norms without the initiative of the parties, leading to the conclusion that the country's collision norms are not of a clear imperative nature.

The terms which express the connection that exists between selected elements of the legal relationship and one legal system, are called focal contacts in the Private International Law at the points of attachment. Today are used different names for them in the local theory, such as: linking circumstance (Katičić, 1971, p.27), link (Sajko, 2009, p.9), decisive facts (Jezdić, 1978, p.59; Muminović, 2008, p. 58) etc., which are listed here for easier understanding in future presentations. Attachment points are used in the multilateral collision standards as a criterion for the selection of the applicable law and their role to the conflict of laws rules point out that, to be more competitive than the right to apply to certain private relationship. Attachment points are used in the multilateral collision standards as a criterion for the selection of the applicable law and their role to the conflict of laws rules point out that, to be more competitive than the right to apply to certain private relationship (Vardi, 1990, p.56). Points of attachment may be an integral element of the choice of law rules, and such a norm can contains a single point of attachment or a combination of multiple attachment points. In fact focal contacts in collisional norms are also the facts on which behalf the foreign element is formed, and they receive the role of focal contacts whenlegislator of the country grants that role by entering them as integral elements of its positive norms of private international law. For which of the focal contacts will be decided by the legislator, depends first of all on the type of private legal relations, as well as the goodwill of one of the types of focal contacts ${ }^{2}$.

In addition to the function of determining the applicable law, the same terms in the Private International Law may have other functions, such as determining when to domestic or foreign courts will be competent to deal with disputes with a foreign element, determination of the concept of foreigner and the extent of the application of laws or international treaties, but in this study, further on, we will keep only the first function.

${ }^{2}$ More about the classification of focal contacts, look Muminovic, E., International Private Law, second edition, Sarajevo 2008, page 83, Varadi, T., Private International Law, Forum, Novi Sad, 1990, page 53

\section{DIVISION OF FOCAL CONTACTS TO DI- RECT AND APPROXIMATE FOCAL CON- TACTS}

\subsection{Introductory considerations}

Criteria for divideing direct binding and approximate focal contacts was carried out according to the width of the powers of the authority (Muminović, 2008, p.83) that applies collision norms. At direct binding focal contacts the legislator has performed weighing and evaluating the decisive facts and factors of localization and on the basis of that evaluation formulated a collision norm.In the collision norms the legislator determine what is considered as a focal contact in an abstract private legal relationship. It is this relationship which is determined by the legislator as a focal contact will take us to the applicable law. Such focal contacts are: nationality, place of residence, the right to find placement ofobjects, the right of the of contract formation, the right of execution of the contract, the right of enforcement of illegal activities, the right of the placewhere the damage occurred, the right of place where it has been acted or where law is determined by the will of the parties. For example, if the terms of conclusion of the contract implicatethe focal contact to be the place of conclusion of the contract as the attachment point, it will connect us directly with the applicable law of the country of origin to give private relationship. Here legislator a priori, using deductive method ${ }^{3}$, which is now dominant in the legislation of European countries, using general clauses, determines abstract collision norms and fixates focal contacts for all future cases. How the application of choice of law rules is of imperative nature, then the domestic court is bound to apply the law applicable to those countries with which there exist focal contacts. In the above mentioned example, we saw that this was a place of conclusion of the contract or the law of the place / country where the contract was concluded.Unlike direct binding focal contacts, at approximate focal contacts the evaluation of focal contacts-point of attachment is left to the court. Here legislator sets only the boundaries and does not establish a direct link to private legal relationships with a particular legal system, but leaves it to the court to be decided in each individual case of the applicable law. The formulation of such norms would be ie.

\footnotetext{
${ }^{3}$ More about the methods of determining the closest ties to international private law see Muminovic, E., International Private Law, second edition, Sarajevo, 2008, page72
} 
"If the parties have not agreed on the law applicable to the contract, the law of the country with which the contract is most closely connected or with which the contract is most closely connected." In this case the Court analyzed the facts and make a decision which contact if focal in the particular respect. Here the court using inductive, posterioric method for one specific case determines focal contact and using it comes to the applicable law. The principle of closest connection as gravity contact in private international law is more up to date. Its recognition and wider application it has found first in the common law, where courts have the role of the creator of norms, and also the norms of international private law. The principle of closest connection as focal contact is increasingly being used in European legislation.

\section{APPROXIMATE FOCAL CONTACTS IN EU- ROPEAN INTERNATIONAL LAW}

We have already mentioned in the introduction that the classification of focal contacts directly binding and approximate focal contacts as main criterion of division takes into account the width of powers authority application. In the approximate focal contacts the valuation of focal contacts or point of attachment is left to the court. Here legislator sets only the boundary, that gives instructions and guidelines (Vardi, 1990, p. 53), but does not establish a direct link of private legal relationship with a particular legal system, but it is left to the court in each individual case to decideabout the applicable law. The formulation of such norms would be. ,If the parties have not agreed on the law applicable to the contract, the law of the country with which the contract is most closely connected or with which the contract is most closely connected." In this case the the court analyzed the facts and the assesseswhich contact is a focal contact in this particular relationship ${ }^{4}$.Here the court using inductive, posterioric method determinesfor one specific case thefocal contact and it using it comes to the applicable law. Therefore, some authors in their classification classified them as objective-subjective focal contacts 5 . The principle of closest connection as focal contact in private international law is more up to date. Its wider application is first found in common law, where courts have the role of creator of norms, even norms of international private law.

\footnotetext{
${ }^{4}$ See Sajko, K .., Private International Law, V. amended Žižanj, Zagreb 2009, page 102

${ }^{5}$ More about in Ročkomanović, M., Principle of the nearest connection and resolution of private international law - from the basic idea to the realization of the purposes relevant rules, Borik Faculty of Law in Nis, 2007, number 50, page 1-26
}

The principle of closest connection as focal contact is increasingly being recognized by European legislation. The increasing use and representation in national legislation leads to a different understanding of this term. In this connection, the term closest connection can be considered as a general doctrinal term elevated to the level of principle, but also as a approximate focal contact coming to his usage in terms of legislation and practical application ${ }^{6}$.

Unlike direct binding focal contacts, the principle of "nearest, closest connection" does not single out one type of connection, that is onefact based on the correlation between private law relations with certain legal system, but requires that the judge in each individual case to examine all connections, taking into account both the quality and quantity of these links. Because of the importance of the principle of the nearest connection in private international law, some authors suggest that this concept should be incorporated into the definition of private international $\mathrm{law}^{7}$, and to give it priority over other focal contacts, while other authors opposed to the principle that higher character stating that such flexibility could undermine legal certainty (Jezdić \& Pak, 1983, p. 151).

\section{1. Criterion of nearest links in codifications of European private international law}

There is no doubt that the principle of closest connection has gone a long way on whichit had his supporters as well as opponents. On that way it passed from the stage of lack of recognition and minimisation all the way to the proclamation of the basic principles and tenets of a codification. Nonetheless there is no room for doubt that this principle in the its way of development had an impact on the basic principles of private international law, which can be best seen in some modern codifications.

Austrian Federal Law of Private International Law of 1978 is the first legal text that is closest to the principle of connections rose to the level of fundamental legal principles. Thus, paragraph 1 , which carries the title "principle of the strongest connection" points out that the private law relations with a foreign element is judged under the law of the country with which the given ratio of the connection is the closest.

\footnotetext{
${ }^{6}$ See Muminovic, E., cited work, page 62

${ }^{7}$ More about in Klasiček, D., Criteria of nearest links in Private International Law, Proceedings of the Faculty of Law, No. 3, 1997, page 221
} 
According to Article 2 of the same paragraph "special rules on applicable law (collision norms)“", as stipulated herein should be considered an expression of the above principles ${ }^{8}$. The law itself does not define the term nearest, strongest, closest connection, but it is left to the judge or other authority that applies the choice of law rule to determine in each specific case. Unlike the previous example, the Swiss federal MLA in 1987 used the clause general deviations from the application of the relevant law. From the formulation of Article 15, folloing that it will not apply the right referred to in this law if it is obvious that the subject of that right has a slight connection, while the connection with other laws is much narrower. The provision of this Article, the Swiss Federal Court applied in one its decision from 1992. The two naturalized US citizens who had their first residece in Texas, after which he was several times unchanged in five different states. At the time of initiating the proceedings one of the spouses had still resides in Switzerland, while the other spouse, previously lived for some time in Switzerland. According to Article 61 (2) MPP Switzerland if the spouses has a common foreign nationality and only one of them is domiciled in Switzerland, the law of which they are nationals of both spouses, that is the right of the United States. However, the court's application of Article 15 of the MLA Switzerland applied the domestic law for reason based on all relevant facts it concluded that the relationship of spouses with common foreign law is insignificant. The closest relationship as a crucial fact for determining the applicable law stipulates the provision on determining the status of individuals. Thus, under Article 23 (2) of the Act for a person who has multiple citizenship, to determine the applicable law it will be relevant to what citizenship with which the person concerned has a closer connection. The principle of closest connection is provided and on the occasion of contractual relations, in situations where the parties have not committed a choice of applicable law, and with it the legislator specifies the closest connection of the contractual relationship with a certain legal order ${ }^{9}$. Following the example of the Swiss legislation, a similar solution can be found in the new MPP of Belgium. Such exception clause identical to the one prescribed by the Swiss can be found in Article 19 of the MLA Belgium.

\footnotetext{
${ }^{8}$ Paragraph 1 MPP Austria

${ }^{9}$ Article117. (2) which states "It is believed the closest connection exists with the State in which the party who is to effect the characteristic performance has his habitual residence or, if they concluded the contract due to a trade or profession has, in which its establishment is located."
}

The closest connection, as a subsidiary of focal contact is foreseen for non-contractual relations for damages and in those situations where the applicable law can not be determined according to the common habitual residence of pests and damaged, that is according to the principle of lex loci delicti Comiso. In such situations the competent law with which the given ratio has the closest connection. Article 104 specifies the facts and circumstances to determine the closest connection in relationships resulting from quasi delicts.And the new MPP of Slovenia in Article 2 contains the same solutions as analyzed in Article 15 of the Swiss law. Furthermore the principle of immediate connection is found and in matters of personal status, when it comes to people with two or more citizenships. In such situations, his nationality shall be of those countries with which he is most closely connected ${ }^{10}$. The principle of immediate connection, as a subsidiary point for the present of attachment-focal contact is found and the provisions on contractual relations. Namely, if the parties failed to chosea applicable law, it shall be governed by that law with which the contractual relationship has the closest connec$\operatorname{tion}^{11}$. The legislator concretized the facts on the basis of which will be appreciated that a contractual relationship has the closest connection with certain legal order, and that is the right of the State in which the official of characteristic prestation has his residence ${ }^{12}$. Analyte solutions in Article 15 of the Swiss law, and Article 2 of the Slovenian law prescribes and MPP of Macedonia in Article 3 (exemption clause), as specific clauses to determine the applicable law. When it comes to the status of a person with two or more nationalities, of which neither of them was Macedonian, in Article 11 lays down identical solutions analyzed in Article 10 of the MLA of Slovenia. Unlike the Slovenian legislator, Macedonian legislator was something concrete so that in addition to the outstanding refinement of the concept nearest connection that we analyzed in Section 20 MPP of Slovenian, Macedonian lawmaker goes a step further and this refinement extends to contracts of carriage. Deviation from the choice of applicable law for damage resulting from an out of the contractual relationship and the application of law with which is givena more closely related relationship, required by Article 33 (2) MPP of Macedonia. Here is therefore the principle of immediate connection accepted as a subsidiary of focal contact, or if it is obvious that a given non-contractual relationship is narrower connected to another order rather than those referred to in the link of the lex loci delicti and the principle benefits, the law by which the ratio is closer related is competent.

\footnotetext{
${ }^{10}$ Article 99 (3) MPP Belgium

${ }^{11}$ Article 10 (3) MPP Slovenia

${ }^{12}$ Article 20 MPP Slovenia
} 
The principle of closest connection as a subsidiary and supplementary focal contact as previously analyzed and solutions are encountered in the legislation of Italy, Germany, Czech, Poland.

Although the doctrine of private international law divided opinions and attitudes when it comes to applying the principle of immediate connection, we can not help but notice that this principle is widespread in contractual relations and we find it in all the mentioned legislation. If we consider that contractual relations are one of the most important segments of private relationships, then there is a need for more precise solutions in terms of determination and application of this principle in national legislations. Great progress on harmonization of contract law at the international level has been achieved by adopting the Rome Convention or the Regulation of the European Parliament and of the Council 593/2008 regarding the EU Member States.

\section{2. Criterion of nearest link in conventional law}

Rome Convention on the applicable lawof contractual relations from 1980 is based on two basic principles for determining the applicable law to contracts - party autonomy will and linking issues ${ }^{13}$. In determining the applicable law, the judge should not engage in the content of potentially relevant laws, but of all the connections that the given contract has with different countries, chooses one that is focal and to permit it to prevail over all other connections. However, in the casewhere a part of the contract, which can be separated more closely connected with another country, on that part of the agreement may be applied the law of that other country ${ }^{14}$. Rome Convention provides solutions to those situations where the characteristic obligation under the contract can not be established, or when using these links it can not get the applicable law.

\footnotetext{
${ }^{13}$ See Articles 3 and 4 of the Rome Convention

${ }^{14}$ See Article 4 paragraph 1 of the Rome Convention
}

In this case, the judge can do nothing but selfapplication of principle of narrowest connection, or that he himself "counts and weighs " focal contacts of contractual relationships and connections with different countries and on this basis to decide which of them will give a appropriate significance $^{15}$. The concretization and refinement of the termof nearest links is given by the Convention for certain types of contracts. So it is considered that contract has the nearest link with the state in which at the time of conclusion of the contract the party performing the characteristic action has his habitual residence or, in the case of a company, association or legal person, or head office. If the contract is concluded in the performance of professional services such parties, it is considered that contract has the closest connection with the country in which the head office or whereanother place of business of the company is, if by the contract specified actionsare executed by that place of business rather than the main business places. For contracts of carriage of goods it is presumed to have the closest relationship with the state in which the carrier at the time of signing the contract has its head office if in that state it has a boarding point, point of deployment or head office of clients.

\footnotetext{
${ }^{15}$ One such example we have the case brought to the court in Dortmund (LG Dortmund, 8 April 1988, 9 IPRAX 1989 S. 51). In fact, it was a contract between producers of steel wool from Germany and manufacturer of sponges for scrubbing the Netherlands. The parties are agreed that the German side to buy sponges exclusively by Dutch company and will sell them in Germany, and that in return, the Dutch company performed an exclusive distribution pad of steel wool produced by the German company. The German firm after breach of contract sued Dutch company seeking damages for nonperformance of this contract. To get to the applicable law, the court relied on Articles 27 and 28 of the Introductory Act by the Civil Code of Germany (E.G.B.G.B.) representing the German codification of the Articles 3 and 4 of the Rome Convention. After analyzing the contract, the court found that both parties were equally bearers of the characteristic obligation. Therefore joined the counting and weighing the relevant contacts with the countries for which the contract was bound to give (Germany and the Netherlands). Special importance court gave the place of conclusion of the contract and the language in which the contract was made (both criteria are suggested to Germany), and concluded that that agreement should apply German law
} 


\section{3. Criterion of nearest links regarding to Regu- lation $864 / 2007$}

General rules laying down the competence of the lex loci damni and lex firmae habitationis communis in certain cases because of their inflexibility may require some deviations and exceptions, which the Regulation provides in the form of an evasive claus$\mathrm{es}^{16}$. Avoiding clause in Article 4 paragraph 3 of the Rome II Regulation states: "When out of all circumstances of the case it is clear that the damaging act is obviously closely associated with the countrydifferent from those referred to in Article 4.Re-1 and 2 of Rome II Regulation, the law of the other country is applied. " Obviously closer connection with another country may be based on the previous relationship between the parties, such as a contract that is closely related to a given wrongful act. Correcting the results of referral should be possible only in extremely rare cases, and therefore, this provision must be strictly interpreted restrictively. This especially comes from the part of which reads "obviously closely associated", as well as from previous provisions which is correcting as they are formednomotechnical, not in the form of assumptions, but in the form of strict rules (Bouček, 2008, pp. 487-504).

The cited provision gives the example of circumstances in which it might, but not necessarily, lead to its acting - existing contractual relationship between the parties. Such previous relationship especially can result from an earlier contract, for example, if the contract is invalid. Precisely under such circumstances it would be possible to apply the law that would be applicable to this contract and thus to respect the legitimate expectations of the parties. If, however, the previous relationship was from a consumer contract or individual employment contract in relation to which the choice of applicable law limited mandatory rules of a normllyapplicable law, this provision would have no effect on such mandatory rules.

However, bearing in mind that the provisions of tort of Rome II Regulationforsees application and legis autonomiae, all objective links among them and nearest links, choosinga applicable law becomesubsidiary, in terms of the order of application ${ }^{17}$.

\footnotetext{
${ }^{16}$ About the balance between the principles of security and requirements for taking into account the circumstances and time see Weintraub, Russell J., Rome II and the Tension between Predictability and Flexibility, Rivista di diritto internazionale privato e processuali, vol. 41, number 3, 2005, page. 561

${ }^{17}$ Article 14 of Rome II
}

\section{4. Criterion of nearest links regarding to Regula- tion 593/2008}

Since Regulation 593/2008 regulates the contractual relations with a foreign element, the primary focal contact under this Regulation is party autonomy. In the contract, theapplicable law is that the parties have cho$\operatorname{sen}^{18}$. In the situation where the parties have not chosen the applicable law, as a subsidiary attachment point is occuring habitual residence of the debtor with characteristic prestation ${ }^{19}$. However, the Regulation provides two situations in which to deviate from the rules laid down in Article 4, paragraph 1, or the application of the law of the country with which the contract is obviously closer related. So if it all the circumstances of the case show that the contract is obviously closer connected with another country than the one mentioned above, the law of that other country ${ }^{20}$, or if on the basis of rules laid down in Article 4, paragraph 1 and 2 can not determine the applicable law, for the contract is the relevant law of the country with which the contract is most closely connected ${ }^{21}$.

What is considered an obvious closer contact is not specified by the Regulation, however, when determining the applicable law of focal contact the nearest, that is the closest connection can be taken into consideration facts such as the location of contract signing, the language in which the agreement is made, the currency in which payment shall be made and similar.

\section{CONCLUSION}

On the basis of deferred solutions in national laws, conventions and regulations of the EU to notice that in the regulation of private-law relations with an international element dominates collision method, a primary role of focal contacts have direct binded focal contacts. So, all the laws that have been the subject of treatment start from the fact that for the majority of private-law relations determinein advance which law will be applicable to this type of relationship, or pre-fixes those facts that are legally relevant to them, giving them a decisive significance and therefore elevating them to the level of focal contacts. All efforts are directed toward understanding of the national legislations in a private law relationship that the application of the lawin this relationship has a substantial connection.

\footnotetext{
${ }^{18}$ Article 3 (1) of the Rome I Regulation

${ }^{19}$ Article 4 (2) of the Rome I Regulation

${ }^{20}$ Article 4 (3) of the Rome I Regulation

${ }^{21}$ Article 4 (4) of the Rome I Regulation
} 
When it comes to approximate focal contacts, then with certainty we can say that the concept has gone a long way, from a lack of recognition, until the promulgation of the basics and guiding starof codification. In this sense, the greatest scope of "the principle of nearest links" can be found in the Austrian legislation, where it was elevated to the level of the principle. Austrian federal law is the first and only in this paper analyzed legal text, which principle strongest, closest connection proclaims the fundamental principle of codification, from which derive all the conflict of laws rules contained in this codification. A significant shift in terms of this principle was entered and in other codification, especially if solutions contained therein are compared with solutions from previous national codification of these countries. Although the words indicative toapproximate focal contacts have significantly lower distribution and secondary subsidiary role, noticeable efforts in the last few decades is given a increasing importance as indicated by the efforts of individual authors to the principle of the nearest links, as the basic and most important element of private international law, should be included in its very definition. Doctrinal and practical importance division focal contacts to direct binding and approximate focal contacts, reflected in the fact that in the application direct focal contacts there is some transfer of competencies, and provide a form of authority with legislative bodies in the courts. Thus, in the application of approximate focal contacts the courts hvae those authorities which decide the application of law with which the concrete relationship is most closely connected while the legislator provides only certain guidelines.

\section{REFERENCES}

Bouček, V. (2008). Rome II Regulation - Communitisation European international tort statute, Proceedings of the Faculty of Law in Split, Number 3, page 487-504

Federal Law of Private International Law of Austria from 1978.

Jezdić, M. (1978). International Private Law, VII edition, Serbia, Belgrade

Jezdić, M., Pak, M., (1983). International Private Law III, Belgrade 1983

Katičić, N. (1971). Essays of Private International Law, Croatia, Zagreb

Klasiček, D. (1997). Criteria of nearest links in Private International Law, Proceedings of the Faculty of Law, No 3, Zagreb

Law of Private International Law of Belgium from 2004.

Law of Private International Law of the Czech Republic 12.04.1963. - This is an inherent law of Czechoslovakia

Law of Private International Law of Macedonia, number 87/07 of 12.07.2007.

Law on Private International Law and Procedure of Slovenia 30.06.1999.

Muminović E. (2008). International Private Law, second edition, B\&H, Sarajevo

Sajko, K . (2009). Private International Law, V. amended edition, Croatia, Zagreb

Varadi, T. (1990). International Private Law, Forum, Serbia, Novi Sad

Regulation (EC) No 864/2007 of the European Parliament and of the Council of July 112007 , on the law applicable to non-contractual obligations (Rome II)

Regulation (EC) No 593/2008 of the European Parliament and of the Council of 17 June 2008 on the law applicable to contractual obligations (Rome I)

Ročkomanović, M. (2007), Principle of the nearest connection and resolution of private international law - from the basic idea to the realization of the purposes relevant rules, Collection of papers of Law School of Niš, No. 50 .

The law on the reform of the Italian Private International Law no. 218, od31. May 1995

The law on the reform of private international law of Germany from 1986. With the appropriate amendments

The law of Private International Law Polish No. 80/2011, of 16.05.2012.

The Swiss Federal Law of 1987, official journal number 1/1998

Weintraub, Rusell J. (2005). Rome II and the Tension between Predictability and Flexibility, Rivista di diritto internazionale privato e processuale, 41 (3) 